\title{
PENGARUH STRATEGI PEMBELAJARAN CONTEXTUAL TEACHING LEARNING DAN INTEGRETED INSTRUCTIONAL TERHADAP KEMAMPUAN BERPIKIR KRITIS SISWA TENTANG ZAKAT
}

\author{
THE INFLUENCE OF THE CONTEXTUAL TEACHING LEARNING STRATEGY AND THE \\ INTEGRATED INSTRUCTIONAL STRATEGY ON THE STUDENT'S CRITICAL THINKING \\ SKILLS CONCERNING ZAKAT
}

\author{
Suhardin \\ Universitas Ibnu Chaldun (UIC) Jakarta \\ Jl. Pemuda I Kav. 97, Rawamangun Jakarta Timur, Daerah Khusus Ibukota Jakarta 13220 \\ email: suhardin@yahoo.com
}

Naskah Diterima: 04 April 2018; Direvisi: 28 Agustus 2018; Disetujui: 28 Agustus 2018

\begin{abstract}
Research aimed to study the influence of Contextual Teaching Learning (CTL) and Integrated Instructional strategy on the student's critical thinking skills concerning zakat. Research conducted in SMP Islam Terpadu (Integrated Islamic Junior High School) Assalam, Jakarta, sampled 60 (sixty) students through random purposive sampling. Research method was an experiment to develop two models of learning strategy, i.e. CTL and IL, as a treatment in improving the student's critical thinking skills concerning zakat. The experiment of two models of learning strategy was conducted in two classes, in three sessions. The third session was used to take the results of the critical thinking skills concerning zakat. Interpreted data analysis suggests the significant influence of the CTL learning strategy and the Integrated Instructional strategy on the student's critical thinking skills concerning zakat. Research concluded that the improvement of the student's critical thinking skills is more affected by the CTL learning strategy than the Integrated Instructional strategy. Therefore, the development of the CTL learning strategy is supposed to be applied to improve the student's critical thinking skills.
\end{abstract}

Keywords: Contextual Teaching Learning (CTL); Critical thinking capability; Instructional strategy: Integreted instructional

\begin{abstract}
Abstrak
Tujuan penelitian ini untuk mengetahui pengaruh strategi pembelajaran Contextual Teaching Learning (CTL) dan Integreted Instructional terhadap kemampuan berpikir kritis siswa tentang zakat. Penelitian ini dilaksanakan di SMP Islam Terpadu Assalam Jakarta dengan mengambil 60 (enam puluh) siswa dengan teknik purposive random sampling. Metode penelitian yang digunakan adalah experiment, mengembangkan dua model strategi pembelajaran, CTL dan IL, sebagai treatment, untuk meningkatkan kemampuan berpikir kritis siswa tentang zakat. Experiment dua strategi pembelajaran dilakukan dalam dua kelas dengan tiga kali pertemuan, pertemuan ketiga, sekaligus pengambilan nilai kemampuan berpikir kritis tentang zakat. Dari interperetasi analisis data yang dilakukan diperloleh bahwa terdapat pengaruh yang signifikan dari strategi pembelajaran contextual teaching learning (CTL) dan Integreted Instructional terhadap kemampuan berpikir kritis siswa tentang zakat. Dengan demikian dapat disimpulkan bahwa strategi pembelajaran Contextual Teaching Learning (CTL) lebih berpengaruh terhadap peningkatan kemampuan berpikir kritis siswa daripada Integreted Instructional. Dengan demikian untuk meningkatkan kemampuan berpikir siswa, perlu menerapkan dan mengembangkan strategi pembelajaran CTL dalam pembelajaran.
\end{abstract}

Kata kunci: Contextual Teaching Learning (CTL); Kemampuan berpikir kritis; Pembelajaran Terpadu; Strategi Pembelajaran 


\section{PENDAHULUAN}

Pembelajaran di ruang kelas oleh guru dan murid, pada umumnya berjalan secara transformatif, sebatas penyampaian informasi, materi, bahan ajar dari guru kepada murid. Keberhasilan guru dalam mengajar di ukur dengan penguasaan siswa terhadap informasi yang disampaikan guru. Siswa yang berprestasi adalah siswa yang menguasai secara komplit semua yang disampaikan oleh guru di ruang kelas. Pembelajaran verbalisme telah menghinggapi hampir semua lembaga pendidikan, baik tingkat dasar malah sampai perguruan tinggi. Siswa terbiasa untuk menghafal semua konsep yang disampaikan guru, malah fatalnya sebagian guru tidak suka dengan siswa yang bertanya, mengkritisasi, dan menyanpaikan sesuatu hal yang baru.

Guru terkesan menyampaikan pelajaran dengan presentasi, mencatatkan dan menghafalkan, tanpa memberi tahukan kepada siswa tentang apa manfaat, dan pentingnya pelajaran yang tengah dipelajari siswa. Malah siswa yang agak cerdas, mempertanyakan tentang sesuatu yang di sampaikan guru, tetapi sebaliknya guru menandai siswa tersebut, memberikan nilai jelek pada aspek sikap, dan terkadang juga menjatuhkan nilai siswa dengan sebelah pihak.

Peraturan Pemerintah Nomor 13 Tahun 2015 tentang Perubahan Kedua Atas Peraturan Pemerintah Nomor 19 Tahun 2005 Tentang Standar Nasional Pendidikan . Dalam PP No. 19 Tahun 2005 tentang standarisasi pendidikan, dijelaskan bahwa standar pendidikan mencakup delapan hal, standar isi, proses, kompetensi lulusan, pendidik dan tenaga kependidikan, sarana dan prasarana, pengelolaan, pembiayaan, penilaian. Dalam aspek standar proses pasal 19 ayat 1, 2 dan 3 dituliskan pada ayat pertama, bahwa proses pembelajaran pada satuan pendidikan diselenggarakan secara interaktif, inspiratif, menyenangkan, menantang, memotivasi peserta didik untuk berpartisipasi aktif, serta memberikan ruang yang cukup bagi prakarsa, kreativitas, dan kemandirian sesuai dengan bakat, minat, dan perkembangan fisik serta psikologis peserta didik. Pada ayat kedua, selain ketentuan sebagaimana pada ayat (1), dalam proses pembelajaran pendidik memberikan keteladanan. Ayat ketiga, setiap satuan pendidikan melakukan perencanaan proses pembelajaran, pelaksanaan proses pembelajaran untuk terlaksananya proses pembelajaran yang efektif dan efisien. ${ }^{1}$

Akibat pembelajaran yang transformatif, informatif, emitatif, membuat siswa full memori miskin kreasi. Siswa dituntut menghafal, menguasai, dan merekonstruksi serta memformulasikan konsep, body pengetahuan yang telah disampaikan guru kepadanya. Hal ini membuat siswa kaku dalam berdialektika dengan permasalahan yang ada. Siswa kurang memahami permasalahan di sekitarnya, dan hanya terpaku untuk mengkopi pengetahuan yang disampaikan guru kepadanya.

Kemampuan berpikir kritis dengan berbasis pembelajaran agaknya sesuatu yang sesuai dengan tata aturan dan regulasi yang ada di negara kita, hal ini dalam rangka mengejar ketertinggalan pendidikan kita dibandingkan dengan pendidikan negara maju di dunia. Berpikir kritis mendorong siswa mengembangkan pemikiran mereka, dengan memberikan ide-ide baru dan menyodorkan topik-topik dalam bentuk permasalahan yang harus di selesaikan dengan pemikiran. ${ }^{2}$

Pada penelitian ini peneliti berusaha untuk melakukan experiment terkait dengan pengaruh sebuah strategi pembelajaran dalam membentuk kemampuan berpikir kritis siswa tentang pembelajaran zakat pada pelajaran Pendidikan Agama Islam (PAI). Strategi pembelajaran contextual teaching learning (CTL) merupakan sebuah strategi pembelajaran yang merangsang siswa untuk menganalisis kontektualisasi pemasalahan yang berikaitan dengan konsep yang tengah dipelajari. Strategi Integratif Learning merupakan strategi untuk mengaitkan beberapa konsep pembelajaran dan berusaha melakukan konstruksi dan formulasi pemahaman berkaitan dengan konsep baru yang tengah dipelajari.

Kedua strategi tersebut sangat membutuhkan penguasaan yang besar dari guru terhadap materi ajar yang tengah disampaikan, berbasis pemikiran kritis dan untuk menguatkan kemampuan pemikiran kritis

${ }^{1}$ Peraturan Pemerintah Nomor 19 Tahun 2005 tentang Standar Nasional Pendidikan, pasal 19, ayat 1, 2 dan 3.

${ }^{2}$ John W. Santrock. 2011. Psikologi Pendidikan. Jakarta: Salemba Humatika. hal. 12 
siswa tersebut, dengan demikian strategi pembelajaran ini berpengaruh terhadap kemampuan berpikir kritis.

Materi ajar zakat pada Pendidikan Agama Islam (PAI) secara kontekstual memerlukan daya kritis yang kuat untuk dapat menciptkan terobosan-terobosan baru terhadap sistem dan tata kelola zakat di tengah masyarakat. Pola pembelajaran yang presentatif dan imitatif sudah tidak memungkinkan lagi untuk memberikan pemahaman mendalam kepada siswa berkaitan dengan konsep zakat. Strategi pembelajaran contextual dan integratif ini adalah sangat strategis untuk digunakan dalam rangka menjelaskan konsep zakat. Permasalahannya dalam penelitian ini, peneliti ingin mengetahui dari dua strategi tersebut yang mana yang lebih efektif dalam meningkatkan kemampuan berpikir kritis siswa.

Penelitian ini penting dilakukan dalam rangka untuk melihat secara empirik apakah strategi pembelajaran berpengaruh terhadap kemampuan berpikir kritis siswa. Kemampuan berpikir kritis siswa perlu diperhatikan oleh guru dengan serius, karena itu menjadi potensi utama dalam menyelesaikan permasalahan kehidupan di masa depan. Kemampuan berpikir kritis akan dapat membuatnya terlatih menggali permasalahan dengan rasional menghubungkan, mengidentifikasi, mengklasifikasi, dan menggali solusi yang tepat dan akurat terhadap sebuah permasalahan. Kualitas individu akan terlihat dari keterampilan berpikir kritis yang dimilikinya. Dengan diketahui bahwa sebuah strategi pembelejaran memiliki effect signinificant terhadap kemampuan berpikir kritis siswa, tugas berikutnya bagaimana mendesain, menyusun dan menata sebuah strategi pembelajaran tersebut, untuk lebih efektif dalam meningkatkan kemampuan berpikir kritis siswa.

Penelitian ini akan mengungkapkan terkait dengan permasalahan pertama, apakah strategi pembelajaran berpengaruh terhadap peningkatan kemampuan berpikir kritis siswa? Kedua, apakah terdapat perbedaan pengaruh antara strategi contextual teaching learning (CTL) dan integarif terhadap kemampuan berpikir kritis siswa tentang zakat.

\section{Kajian Literatur}

John Dewey mengatakan berpikir kritis adalah pertimbangan yang aktif, terus menerus dan teliti mengenai sebuah keyakinana atau bentuk pengetahuan yang diterima begitu saja dengan menyertakan alasan-alasan yang mendukung dan kesimpulan-kesimpulan yang rasional. ${ }^{3}$ Menurut Ennis berpikir kritis adalah berpikir secara beralasan dan reflektif dengan menekankan pada pembuatan keputusan tentang apa yang harus dipercayai atau dilakukan. ${ }^{4}$ Paul berpendapat berpikir kritis adalah proses disiplin secara intelektual di mana seseorang secara aktif dan terampil memahami, mengaplikasikan, menganalisis, mensintesakan, dan/atau mengevaluasi berbagai informasi yang dia kumpulkan atau yang dia ambil dari pengalaman, dari pengamatan (observasi), dari refleksi yang dilakukannya, dari penalaran, atau dari komunikasi yang dilakukan. ${ }^{5}$

Pendapat berpikir kritis sangat beragam namun secara umum berpikir kritis merupakan suatu proses berpikir kognitif dengan menggabungkan kemampuan intelektual dan kemampuan berpikir untuk mempelajari berbagai disiplin ilmu dalam kehidupan, sehingga bentuk ketrampilan berpikir yang dibutuhkan pun akan berbeda untuk masing-masing disiplin ilmu. Berpikir kritis berarti berpikir secara terus menerus dan aktif mengoptimalkan daya nalarnya, tidak mau menerima begitu saja, dan selalu mencermati berbagai informasi atau pengetahuan yang menjadi objek pemikirannya. Berpikir kritis tidak berarti menyerang atau menjatuhkan orang lain, melainkan kemampuan berargumen secara rasional sehinggga menemukan kebenaran sebuah pandangan.

Glaser berpendapat bahwa seseorang dapat dikatakan memiliki kemampuan berpikir kritis, jika kerja nalar dan kemampuan argumentasinya melibatkan tiga hal, yakni 1) sikap menanggapi berbagai persoalan,

${ }^{3}$ John Dewey. 2012. Critical Thinking dalam Kasdin Sihotang dan Febiana Rima, K. Jakarta: Pustaka Sinar Harapan. hal. 3.

${ }^{4}$ Ennis, Robert, H. 1962. A concept of critical thinking. Cambridge: Harvard Educational Review. Vol 32(1). hal..81-111.

${ }^{5}$ Richard. W. Paul. 1996. Logic as Theory of Validation: An essay in Philosophical logic. Santa Barbara: University of California, hal.102. 
menimbang berbagai persoalan yang dihadapi dalam pengalaman dan kemampuan memikirkannya secara mendalam, 2) pengetahuan akan metode berpikir/bernalar dan inkuiri logis, 3) ketrampilan atau kecakapan menerapkan metode-metode tersebut. ${ }^{6}$ Berpikir kritis bervariasi sesuai dengan motivasi yang mendasarinya.Bila didasarkan pada motif egois, sering diwujudkan dalam manipulasi terampil ide dalam pelayanan sendiri, atau kelompok seseorang seseorang kepentingan pribadi. Oleh sebab itu biasanya intelektual cacat, namun pragmatis sukses mungkin. Bila didasarkan pada fairmindedness dan integritas intelektual, biasanya dari tatanan yang lebih tinggi intelektual, meskipun tunduk pada tuduhan "idealisme" oleh orang-orang terbiasa dengan penggunaan egois.

Nicholas Burbules dan Rupert Berk menyatakan bahwa perangkat berpikir kritis utamanya adalah kemampuan logika formal dan informal, analisis konseptual dan epistemologis. Nicholas Burbules dan Rupert Berk juga mengutip Harvey Siegel yang menyatakan bahwaberpikir kritis inilah yang membuahkan nalar kreatif di sisi lain. ${ }^{7}$ Ketika berpikir kritis berupaya untuk mengkritik kesalahan logika berpikir, maka di sisi lain dengan pola pikir yang sama yakni pola pikir yang tidak linier dan berpikir dari perspektif lain yang berbeda dari awal berpikir kritis dapat membuahkan gagasan kreatif tertentu. Pope mengatakan bahwa definisi kreativitas secara umum cenderung pada konsep "kreativitas" sebagai sesuatu yang baru dan bernilai (new and valuable) atau ide baru yang dapat diterima atau layak/patut (novel and appropriate). ${ }^{8}$ Pope juga menyatakan bahwa kreativitas secara umum merupakan ide-ide baru yang bernilai, orisinal, juga tepat dan adaptif sebagai solusi masalah yang sedang terjadi. ${ }^{9}$ Dengan kata lain, kreativitas adalah upaya mengkreasi (to create) atau mencipta

${ }^{6}$ Edward. Glaser. 1994. An experiment in the Development of Critical Thinking. Columbia: Teacher's College Columbia University. hal.78.

${ }^{7}$ Ibid, hal. 9

${ }^{8}$ Stenberg, Rob Pope. 2005. Creativity: Theory, History, and Practice. London \& New York: Routledge. hal. 57.

${ }^{9}$ Ibid, hal. 59 ide-ide baru, bisa juga disebut inovasi, cara atau strategi baru untuk memenuhi kebutuhan manusia dan memecahkan masalah-masalah yang timbul. Di sinilah karakterisitk kreatif adalah mencipta ide-ide baru yang bernilai. Di sisi lain, Teori Kritis berangkat dari titik fokus yang berbeda, bahwa Teori Kritis merupakan serangkaian gagasan dan kritik yang ditujukan terhadap pengetahuan, sistem sosial, politik, ekonomi, budaya dan lainnya yang telah membuahkan banyak problem sosial. Tujuan utama pedagogi kritis adalah membangun kesadaran kritis (critical consciousness) seseorang. ${ }^{10}$

Berpikir kritis adalah salah satu proses berpikir tingkat tinggi yang dapat digunakan dalam pembentukan sistem konseptual siswa. Kemapuan berpikir kritis merupakan kemampuan yang sangat esensial untuk kehidupan, pekerjaan dan efektif dalam semua aspek kehidupan lainnya. Berpikir secara kritis menantang individu untuk menelaah asumsi tentang informasi terbaru dan untuk menginterprestasikan serta mengevaluasi uraian dangan tujuan mencapai simpulan suatu perspektif baru.

Zakat menurut Sayyid Sabiq adalah nama dari sesuatu hak Allah yang dikeluarkan seseorang kepada fakir miskin. Dinamakan zakat dikarenakan mengandung harapan untuk mendapatkan berkah, membersihkan dan memupuk jiwa dengan berbagai kebaikan. ${ }^{11}$

Menurut Hafiduddin zakat adalah salah satu pilar penting dalam ajaran Islam, menurut beliau secara etimologis, zakat memiliki arti kata berkembang (an-namaa), mensucikan (atthaharatu) dan berkah (al-barakatu). Sedangkan secara terminologis, zakat mempunyai arti mengeluarkan sebagian harta dengan persyaratan tertentu untuk diberikan kepada kelompok tertentu (Mustahik) dengan persyaratan tertentu pula. ${ }^{12}$

Diantara solusi terhadap permasalahan ummat Islam menurut al-Qardhawi adalah

${ }^{10}$ Peter McLaren \& Peter Leonard (eds.). 1993. Paulo Freire: A Critical Encounter (London \& New York: Routledge. hal. 104

${ }^{11}$ Sayyid Sabiq. 2006. Figih Sunnah. Jakarta: Pena Pundi Aksar. hal. 497.

${ }^{12}$ D. Hafidhuddin. 2002. Zakat dalam perekonomian modern. Jakarta: Gema Insani Press. hal. 78. 
dengan zakat, beliau mengatakan bahwa tujuan mendasar ibadah zakat itu adalah untuk menyelesaikan berbagai macam persoalan sosial seperti pengangguran, kemiskinan, dan lain-lain. Sistem distribusi zakat merupakan solusi terhadap persoalan-persoalan tersebut dengan memberikan bantuan kepada orang miskin tanpa memandang ras, warna kulit, etnis, dan atribut-atribut keduniawian lainnya. ${ }^{13}$

Zakat sebagai sebagian dari bentuk ibadah khusus (Ibadah mahdah) dan ibadah umum (ghairu mahdah) memiliki banyak tuntutan untuk dikembangkan secara kreatif, seperti yang dikemukakan oleh Eldin, beliau mencoba untuk menganalisa fungsi alokatif dan stabilisator zakat dalam perekonomian. Ia menyatakan bahwa fungsi alokatif zakat diekspresikan sebagai alat atau instrumen untuk memerangi kemiskinan. Namun demikian, hendaknya dalam pola pendistribusiannya, zakat tidak hanya diberikan dalam bentuk barang konsumsi saja melainkan juga dalam bentuk barang produksi. Ini dilakukan ketika mustahik memiliki kapasitas dan kemampuan untuk mengolah dan melakukan aktivitas produksi. Ia pun mendorong distribusi zakat dalam bentuk ekuitas, yang diharapkan akan memberikan dampak yang lebih luas terhadap kondisi perekonomian. ${ }^{14}$

Dari deskripsi teoretik di atas, terlihat bahwa zakat secara implementatif mengandung banyak permasalahan, tetapi secara substantif, doktrin zakat tidak ada permasalahan lagi, ini merupakan sebuah doktrin keislaman untuk berbagi terhadap sesama. Tetapi implementatif, pengelolaan zakat menunggu ide-ide kreatif untuk dikemas dengan memanfaatkan teknologi modern. Dengan demikian kemampuan berpikir kritis bagi siswa terhadap pengelolaan zakat perlu ditumbuh kembangkan.

Dalam penelitian ini yang kami maksud dengan kemampuan berpikir kritis tentang zakat adalah kemampuan siswa dalam menganalisis permasalahan penerapan zakat,

\footnotetext{
${ }^{13}$ Y. Al-Qardawi. 1993. Fiqhuz Zakat. Jakarta: Litera Antar Nusa. hal. 507.

${ }^{14}$ S. I. T. El-Din. 1986. Allocative and Stabilizing Functions of Zakat in an Economy. Journal of Islamic Banking and Finance. Vol. 3(4).
}

infak dan sadakah (ZIS) di tengah mesyarakat dan berusaha menggali beberapa ide, gagasan, pemikiran yang solutif terhadap permasahan tersebut.

Contextual Teaching Learning (CTL) merpakan suatu konsepsi yang membantu guru mengaitkan konten mata pelajaran dengan situasi dunia nyata dan memotivasi siswa membuat hubungan antara pengetahuan dan penerapannya dalam kehidupan mereka sebagai anggota keluarga, warga negara, dan tenaga kerja. ${ }^{15}$

CTL membuat siswa mampu menghubungkan isi dari subjek-subjek akademik dengan konteks kehidupan keseharian mereka untuk menemukan makna. ${ }^{16}$ Lebih lanjut Elaine mengatakan ada delapan komponen dalam mengembangkan CTL (1) membuat keterkaitan-keterkaitan yang bermakna; (2) melakukan pekerjaan yang berarti; (3) melakukan pembelajaran yang diatur sendiri; (4) bekerja sama; (5) berpikir kritis dan kreatif; (6) membantu individu untuk tumbuh dan berkembang; (7) mencapai standar yang tinggi; (8) menggunakan penilaian autentik. ${ }^{17}$

Blanchard yang dikutip oleh Kasihani mengemukakan strategi yang dilakukan dalam mengembangkan CTL adalah dengan langkahlangkah sebagai berikut: (1) menekankan pentingnya pemecahan masalah; (2) mengakui perlunya kegiatan belajar mengajar dilakukan dalam berbagai konteks seperti di rumah, masyarakat dan tempat kerja; (3) mengajar siswa memantau dan mengarahkan pembelajaran mereka agar menjadi siswa yang dapat belajar sendiri; (4) menekankan pelajaran pada konteks kehidupan siswa yang berbedabeda; (5) mendorong siswa belajar dari sesama teman dan belajar bersama; (6) menggunakan penilaian otentik. ${ }^{18}$

\footnotetext{
${ }^{15}$ Trianto. 2009. Mendesain Model Pembelajaran Inovatif-Progresif Konsep, Landasan, dan Implementasinya Pada Kurikulum Tingkat Satuan Pendidikan (KTSP). Jakarta: Kencana Prenada Media Group. hal. 104-105.

${ }^{16}$ Elaine B. Johnson. 2002. Contextual Teaching Learning. California: Thousan Oak,. hal. 64.

${ }^{17}$ Ibid. hal. 65-66.

${ }^{18}$ Kasihani. 2002. Contextual Teaching and Learning (CTL) Pengajaran dan Pembelajaran Kontekstual. Malang: Jurnal Vol. 2. Hal. 3-4.
} 
Wasis mengatakan bahwa pembelajaran kontekstual memiliki ciri khusus, yaitu menyediakan berbagai fitur sehingga konten dalam perangkat dapat dikaitkan dengan kehidupan nyata, serta memiliki berbagai pilihan aktivits sehingga siswa dengan berbagai gaya belajar dan tingkat kemampuan dapat melakukan hand on activities dan mind on activities sesuai dengan lingkungan belajarnya. ${ }^{19}$ Model pembelajaran CTL lebih menekankan pembelajaran berpusat kepada siswa. Sebagian waktu pembelajaran digunakan oleh siswa untuk membangun pengetahuannya sendiri melalui berbagai kegiatan, antara lain praktikum, diskusi, presentasi, mengerjakan LKS atau tugas-tugas lain, membaca untuk menemukan konsep atau kalimat-kalimat kunci. Peran guru dalam bentuk pembimbingan tetap dibutuhkan selama kegiatan-kegiatan tersebut, tetapi lebih bersifat fasilitator bukan decision maker. ${ }^{20}$

Tita Rostiawati mengatakan bahwa CTL merupakan suatu konsep pembelajaran yang mengaitkan antara materi pelajaran yang dipelajari siswa dengan konteks dimana materi tersebut digunakan dengan menggunakan pengalaman dan pengetahuan sebelumnya untuk menemukan dan membangun pengetahuannya sendiri. Materi pembelajaran akan bermakna bagi siswa jika mereka mempelajari materi tersebut melalui konteks kehidupan mereka. ${ }^{21}$

Dengan demikian strategi pembelajaran CTL dilakukan dengan langkah sebagai berikut (1) Memberikan masalah; (2) siswa mendiskusikan masalahdan mengidentifikasi masalah; (3) pembelajaran pada konteks kehidupan siswa; (4) belajar bersama (colaboration learning); (5) penilaian otentik.

Menurut Paul Strategi Pembelajaran Integaratif merupakan sebuah model pengajaran untuk membantu siswa mengembangkan pemahaman mendalam

${ }^{19}$ Wasis. 2006. Contextual Teaching and Learning (CTL) Dalam Pembelajaran Sains-Fisika SMP. Surabaya: Jurnal Cakrawala Pendidikan. Februari Tahun XXV No. 1. hal. 14.

${ }^{20}$ Loc.cit..

${ }^{21}$ Tita Rostiawati. 2013. Penerapan Model Pembelajaran CTL Pada Bahan Ajar Geometri dan Pengukuran di Sekolah Dasar. Bandung: UPI Press. hal. 2. tentang bangunan pengetahuan sistematis sambil secara bersamaan melatih keterampilan berpikir kritis mereka. ${ }^{22}$

Model Pembelajaran integratif dapat di visualisasikan pada Gambar 1 .

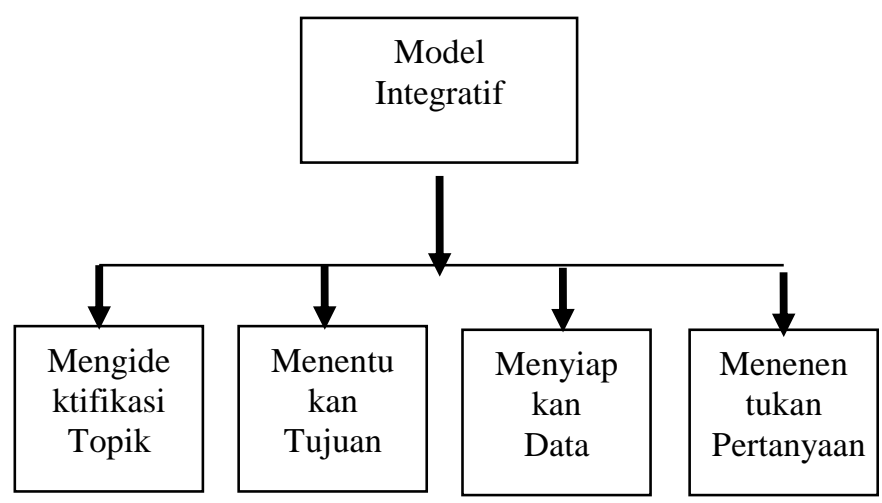

Gambar 1. Model integratif Paul Eggen ${ }^{23}$

Menurut Fogarty pembelajaran integratif merupakan suatu model pendekatan dalam pembelajaran yang secara sengaja mengaitkan beberapa aspek dalam antarmata pelajaran yang diintegrasikan. Dengan model integratif ini, maka siswa akan memperoleh pengetahuan dan keterampilan secara utuh, sehingga pembelajaran menjadi bermakna bagi siswa. Bermakna dalam hal ini mengandung pengertian siswa secara tidak langsung mempelajari dan memahami konsep-konsep yang mereka pelajari melalui pengalaman langsung dan nyata yang menghubungkan antar konsep antar mata pelajaran yang diintegrasikan. ${ }^{24}$

Sunhaji dalam penelitiannya tentang Model Pempelajaran Integratif Pendidikan Agama Islam dengan dengan Saint, memberikan komentar tentang strategi pembelajaran integratif sebagai berikut: "Pembelajaran integratif lebih menekankan pada keterlibatan siswa secara aktif dalam belajar. Hal demikian sesuai dengan harapan teori belajar konstruktivisme yang menghendaki bahwa siswa belajar sesuai dengan pengalamannya. Belajar menurut teori ini adalah upaya keras yang sangat personal, guru bertindak sebagai fasilitator yang meyakinkan

${ }^{22}$ Paul, Eggen. 2012. Strategi dan Model Pembelajaran Mengajarkan Konten dan Keterampilan Berpikir. Jakarta: Indeks. hal. 259.

${ }^{23}$ Ibid. hal. 262.

${ }^{24} \mathrm{~F}$. Fogarty. 1991. How to Integrative The Curricula (Palatine, Illionis: Skygh Publishing Inc. hal. 76. 
siswa untuk menemukan sendiri prinsip-prinsip dan mengkonstruksi pengetahuan dengan memecahkan problem-problem yang realistis". 25

Menurut Fauzan pembelajaran integratif atau terpadu yaitu model pembelajaran yang mencoba memadukan beberapa pokok bahasan dengan pokok bahasan lain dalam satu mata pelajaran. Selain itu bisa juga antar mata pelajaran (lintas kurikulum), dengan langkah, kegiatan awal, kegiatan inti, dan kegiatan akhir. $^{26}$

Dari uraian di atas, terlihat bahwa pengembangan strategi pembelajaran integratif dengan langkah: (1) mengidentifikasi topik; (2) menentukan tujuan pembelajaran dengan merencakan berpikir kritis siswa; (3) menyiapkan representasi data, mempersiapkan data, memperlihatkan data secara efektif; dan 4) menentukan pertanyaan.

\section{Kerangka Teoritik}

Model strategi pembelajaran integratif memberikan kombinasi fakta, konsep, dan generalisasi di dalam satu matrik. Model ini didasarkan pada pandangan bahwa pembelajar membangun pemahaman mereka sendiri tentang topik-topik yang mereka pelajari ketimbang merekam pelajaran yang dalam bentuk yang sudah tertata secara sistematis. ${ }^{27}$ Dalam penelitian indah Sugiarti, beliau menemukan bahwa strategi integrasi dalam pelajaran Bahasa Indonesia dapat memberikan kesempatan kepada siswa untuk mengeksplor atau menjelajah materi secara terbuka dan mendalam sehingga siswa benar-benar menjadi subjek pembelajaran. ${ }^{28}$ Lisa Ariyanti dalam penelitiannya tentang pengaruh penggunaan model pembelajaran integratif terhadap hasil belajar sifat koligatif larutan, menyimpulkan bahwa paradigma pembelajaran yang hanya terpusat pada guru dapat diubah dengan

\footnotetext{
${ }^{25}$ Sunhaji. 2014. Model Pempelajaran Integratif Pendidikan Agama Islam dengan dengan Saint. Jurnal Insania,. Vol. 19(2). hal. 340.

${ }^{26}$ Fauzan. Model-Model Pembelajaran Integratif. http://bdkbandung.kemenag.go.id/jurnal/324-modelpembelajaran-integratif (diakses 28 Oktober 2017).

${ }^{27}$ Paul Eggen, op. cit.. hal. 259.

${ }^{28}$ Indah, Sugiarti. 2007. Implementasi Model Pembelajaran Integratif Exploratif Dalam Pembelajaran Bahasa Indonesia di SMP. Jurnal ..... hal. 186.
}

strategi pembelajaran integratif. Strataegy ini menurut beliau dapat membuat guru benarbenar menguasai materi pembelajaran yang akan disampaikan kepada siswa, sehingga menggiring siswa berpikir kritis, pohan berpendapat untuk jangka panjang model pembelajaran integratif mempunyai dampak positif dalam mengembangkan pemikiran kritis siswa. $^{29}$

Selain stertegy pembelajaran integratif, Elaine mengembangkan strategi pembelajaran Cotextual Teaching Learning, sebuah sistem menyeluruh, terdiri dari bagian-bagian yang terhubung. CTL membuat siswa mampu menghubungkan isi dari subjek-subjek akademik dengan konteks kehidupan keseharian mereka untuk menemukan makna. ${ }^{30}$ Lebih lanjut Elaine menyusun formulasi penerapan CTL dalam pembelajaran dengan langkah; (1) membuat keterkaitan-keterkaitan yang bermakna; (2) melakukan pekerjaan yang berarti; (3) melakukan pembelajaran yang diatur sendiri; (4) bekerja sama; (5) berpikir kritis dan kreatif; (6) membantu individu untuk tumbuh dan berkembang; (7) mencapai standar yang tinggi dan (9) menggunakan penilaian yang autentik. ${ }^{31}$ Trianto mengemukakan bahwa pembelajaran contextual dirancang untuk merangsang 5 (lima) bentuk dasar dari pembelajaran; (1) relating, menghubungkan konsep baru dengan sesuatu yang telah diektahui; (2) experiencing, guru memberikan kegiatan yang hands-on kepada siswa; (3) applying, menerapkan konsep-konsep; (4) cooperating, saling berbagi, merespon, dan berkomunikasi; (5) transfering, menggunakan pengetahuan dalam konteks baru. ${ }^{32}$

Berpikir kritis meliputi berpikir secara replektif dan produktif serta mengevaluasi

\footnotetext{
${ }^{29}$ Lisa, Ariyanti Pohan. 2015. Pengaruh Penggunaan Model Pembelajaran Integratif Terhadap Hasil Belajar Sifat Koligatif Larutan. Jurnal Wahana Inovasi. Vol. 4(1). hal. 130.

${ }^{30}$ Elaine B. Johnson. 2007. Contextual Teaching Learning Menjadikan Kegitan Belajar-Mengajar Mengasyikkan dan Bermakna (Bandung: Mizan Media Utama. hal.64-65.

${ }^{31}$ Ibid. hal. 65-66.

${ }^{32}$ Trianto. 2009. Mendesain Model Pembelajaran Inovatif-Progresif Konsep, Landasan dan Implementasinya pada Kurikulum Tingkat Satuan Pendidikan (KTSP). Jakarta: Kencana Prenada Media Group. hal. 109.
} 
bukti. ${ }^{33}$ Kemampuan ini akan membuat seorang individu terlatih untuk mengumpulkan fakta, mengidentifikasi, mengkategorisasi, menggeneralisasi, mengkonstruksi, menghubungkan dan memecahkan masalah dengan fakta dan data secara akurat dapat dipertanggungjawabkan secara keilmuan. Kemampuan ini perlu diasah dengan serius, dengan menggali, mempelajari, meneliti lebih dalam, menganalisis lebih seksama treatmenttreatment khusus yang efektif untuk menciptakan kemampuan tersebut. Strategi pembelajaran Contextual Teaching Learning dan Integreted Learning keduanya memiliki efektifitas terhadap kemampuan berpikikir kritis siswa, tetapi permasalahannya manakah yang lebih efektif dari kedua strategy pembelajaran tersebut terhadap peningkatan kemampuan berpikir kritis siswa.

Pembelajaran zakat di sekolah pada umumnya cendrung indoktrinasi dengan menyuguhkan kepada siswa konsep baku tentang zakat, padahal zakat dalam prespektif kontemporer sebuah pelajaran yang memiliki dinamika faktual dan konseptual yang menarik untuk di kemas secara kreatif, sehingga memberikan tantangan kepada guru dan siswa. Dua strategi pembelajaran yang telah dikembangkan dalam kajian konseptual dan kerangka teoretik ini, yakni contextual teaching learning (CTL) dan integratif learning, kedua-duanya memberikan pondasi berpikir kritis kepada siswa, maka dalam penelitian ini, peneliti berusaha untuk membandingkan efektifitas kedua strategi ini dalam mempengaruhi tingkat kemampuan berpikir kritis siswa tentang zakat.

\section{Hipotesis}

Dari kerangka teoritik di atas peneliti dapat mengemukakan hipotesis strategi pembelajaran Contextual Teaching Learning (CTL) lebih berpengaruh dari Instructional Integreted terhadap kemampuan berpikir kritis siswa tentang zakat.

\section{METODOLOGI PENELITIAN}

Metode penelitian yang digunakan adalah metode eksperimen dengan variabel

${ }^{33}$ John W. Santrock. 2011. Psikologi Pendidikan. Jakarta: Salemba Humanika. hal. 11. terikat adalah Kemampuan berpikir Kritis tentang zakat. Treatmentnya strategi pembelajaran menjadi dua, yaitu Contextual Teaching Learning (CTL) dan Instructional Integreted (II). Adapun desain penelitian yang digunakan adalah factorial sederhana (simple factorial design) $2 \times 1$ dengan matrik rancangan eksperimen yang diadaptasi dari Jack R. Fraenkel dan Norman E Wallen.

Populasi yang akan di teliti meliputi populasi target adalah siswa SMP se Kecamatan Pasar Minggu dan populasi terjangkau (target population) ${ }^{34}$ adalah siswa SMP Assalam Jakarta, dengan sampel kelas tertentu yang akan diambil secara simple random sampling. ${ }^{35}$ Sampel diambil dengan menggunakan tekhnik sampling purposive random sampling, dimana penelitian ini mengambil sampel dengan strata tertentu yakni siswa yang tengah belajar zakat. Dalam pemilihan sampel juga terlibat random sampling untuk menentukan siswa kelas mana yang akan terlibat dalam penelitian. Dilakukan dengan mengambil secara random bukan individu namun kelompok-kelompok yang mempunyai karakteristik yang relatif sama. ${ }^{36}$

Perlakuan peneltian adalah pelaksanaan eksperimen dalam bentuk pembelajaran tentang pengetahuan tentang zakat. ${ }^{37}$ Lebih detail perbedaan kedua treatment di atas dapat digambar dalam Tabel 1.

Materi pembelajaran adalah zakat dan implementasinya dengan tematik dan integratif. Diberikan selama 3 kali pertemuan, setiap pertemuan 80 menit. Untuk menguji hipotesis penelitian dan memperkirakan besarnya perbedaan antara variable, digunakan analisis varians. Agar analisis varian dapat digunakan, maka persyaratan analisis harus dipenuhi. Persyaratan analisis adalah bahwa data harus diambil secara acak, variabelvariabel harus independen, data penelitian yang diperoleh harus berdistribusi normal, dan semua variansnya homogen.

${ }^{34}$ Meredith D. Gall. 2007. An Introduction Educational Research. Boston: Pearson. hal. 166.

${ }^{35}$ Ibid. hal. 170.

${ }^{36}$ Walter, R. B., Meredith, D. Gall. 1983. Educational Research. New York: Longmann. hal. 249250 .

${ }^{37}$ Jhon, J. Shaughnessy. 2012. Research Methods in Psychology. New York: McGraw-Hill. hal. 250. 
Tabel 1. Rincian treatment

\begin{tabular}{|c|l|c|l|}
\hline No. & \multicolumn{1}{|c|}{ CTL } & No. & \multicolumn{1}{|c|}{ Integreted Learning } \\
\hline 1. & Pengamatan (observation) & 1. & Indentifikasi Topik \\
\hline 2. & Bertanya (questioning) & 2. & Menentukan Tujuan Belajar \\
\hline 3. & Dugaan (hyphotesis) & 3. & Menyiapkan Data \\
\hline 4. & Pengumpulan data (gathering) & 4. & Menyampaikan Data \\
\hline 5. & Penyimpulan (conclution) & 5. & Menentukan Pertanyaan \\
\hline
\end{tabular}

\section{HASIL DAN PEMBAHASAN}

\section{Hasil}

Deskripsi hasil penelitian yang berupa skor kemampuan berpikir kritis siswa tentang zakat yang memperoleh paket pembelajaran Contextual Teaching Learning (CTL) ( $\left.\mathrm{A}_{1}\right)$ dihitung melalui sample berjumlah 30 responden. Ukuran statistik deskriptif yang dihitung antara lain; mean= 78,96; median= 79; modus $=78 ;$ standar deviasi 6,31; variance $=39,89$; nilai minimum $=65$; nilai maksimum $=91$; range $=26$.

Berdasarkan distribusi frekuensi Tabel 2., dapat diperlihatkan bahwa kedudukan skor yang berada di bawah mean $(78,96) 7$ (tujuh) responden $(23,33 \%)$, skor yang berada dalam rentang mean $=11$ (sebelas) responden $(36,66 \%)$, dan skor yang berada di atas mean $=$ 12 (dua belas) responden $(40,00 \%)$.

Deskripsi hasil penelitian yang berupa skor kemampuan berpikir kritis siswa tentang zakat yang memperoleh paket pembelajaran Instuctional Integreted $\left(\mathrm{A}_{2}\right)$ dihitung melalui sample berjumlah 30 responden. Ukuran statistik deskriptif yang dihitung antara lain: mean $=72,86 ;$ median $=71 ;$ modus $=65$; Standar Deviasi 8,89; Variance $=79,15$; Nilai Minimum $=59$; Nilai Maksimum $=92$; Range $=$ 33.

Tabel 2. Distribusi frekuensi skor kemampuan berpikir kritis tentang zakat siswa yang memperoleh paket strategi CTL $\left(\mathrm{A}_{1}\right)$

\begin{tabular}{|c|c|c|c|c|c|c|}
\hline No & $\begin{array}{c}\text { Kelas } \\
\text { Interval }\end{array}$ & $\begin{array}{l}\text { Batas } \\
\text { Bawah }\end{array}$ & $\begin{array}{c}\text { Batas } \\
\text { Atas }\end{array}$ & $\begin{array}{c}\text { Frekuensi } \\
\text { Absolut }\end{array}$ & $\begin{array}{c}\text { Frekuensi } \\
\text { Relatif }\end{array}$ & $\begin{array}{l}\text { Frekuensi } \\
\text { Kumulatif }\end{array}$ \\
\hline 1. & $65-70$ & 64,5 & 70,5 & 3 & $10,00 \%$ & $10,00 \%$ \\
\hline 2. & $71-75$ & 70,5 & 75,5 & 4 & $13,33 \%$ & $23,33 \%$ \\
\hline 3. & $76-80$ & 75,5 & 80,5 & 11 & $36,66 \%$ & $59,99 \%$ \\
\hline 4. & $81-85$ & 80,5 & 85,5 & 9 & $30,00 \%$ & $89,99 \%$ \\
\hline 5. & $86-90$ & 85,5 & 90,5 & 3 & $10,00 \%$ & $100.0 \%$ \\
\hline \multicolumn{4}{|c|}{ Jumlah } & 30 & $100 \%$ & $100 \%$ \\
\hline
\end{tabular}

Tabel 3. Distribusi frekuensi skor kemampuan berpikir kritis tentang zakat siswa yang memperoleh paket strategi pembelajaran interagratif $\left(\mathrm{A}_{2}\right)$

\begin{tabular}{|c|c|c|c|c|c|c|}
\hline No & $\begin{array}{c}\text { Kelas } \\
\text { Interval }\end{array}$ & $\begin{array}{l}\text { Batas } \\
\text { Bawah }\end{array}$ & $\begin{array}{c}\text { Batas } \\
\text { Atas }\end{array}$ & $\begin{array}{c}\text { Frekuensi } \\
\text { Absolut }\end{array}$ & $\begin{array}{c}\text { Frekuensi } \\
\text { Relatif }\end{array}$ & $\begin{array}{l}\text { Frekuensi } \\
\text { Kumulatif }\end{array}$ \\
\hline 1. & $58-65$ & 57,5 & 65,5 & 7 & $23,33 \%$ & $23,33 \%$ \\
\hline 2. & $66-73$ & 65,5 & 73,5 & 13 & $43,33 \%$ & $66,66 \%$ \\
\hline 3. & $74-81$ & 73,5 & 81,5 & 4 & $13,33 \%$ & $79,99 \%$ \\
\hline 4. & $82-89$ & 81,5 & 89,5 & 5 & $16,66 \%$ & $96,65 \%$ \\
\hline 5. & $90-97$ & 89,5 & 97,5 & 1 & $3,33 \%$ & $100,0 \%$ \\
\hline \multicolumn{4}{|c|}{ Jumlah } & 30 & $100 \%$ & $100 \%$ \\
\hline
\end{tabular}

Berdasarkan distribusi frekuensi Tabel 3., dapat diperlihatkan bahwa kedudukan skor yang berada di bawah mean $(72,86) 20$ (dua puluh) responden $(66,66 \%)$, skor yang berada dalam rentang mean $=4$ (empat) responden 
$(13,33 \%)$, dan skor yang berada di atas mean= 6 (enam) responden $(19,99 \%)$.

Sebelum dilakukan pengujian inferensial, terlebih dahulu dilakukan pengujuan persyaratan analisis data yang meliuputi: uji normalitas, uji homogenitas, uji linieritas, uji keberartian regresi dan uji kesejajaran regresi, semuanya telah teruji dan memenuhi persyaratan untuk dilakukan uji hipotesis.

Berdasarkan hasil perhitungan normalitas dari Tabel 3., ternyata signifikansi (2-tailed) diperoleh 0,421 lebih besar dari 0,05, (sign= $0,421>0,05)$ maka $H_{0}$ di terima, data berdistribusi normal.

Tabel 3. Hasil uji normalitas kelompok data

One-Sample Kolmogorov-Smirnov Test

\begin{tabular}{|c|c|c|c|}
\hline & & IL & CTL \\
\hline \multicolumn{2}{|l|}{$\mathrm{N}$} & & 30 \\
\hline & Mean & 72,8667 & 78,9667 \\
\hline \multirow[t]{2}{*}{ Normal Parameters ${ }^{\mathrm{a}, \mathrm{b}}$} & Std. & 880685 & 631628 \\
\hline & Deviation & 0,09000 & \\
\hline \multirow{3}{*}{$\begin{array}{l}\text { Most Extreme } \\
\text { Differences }\end{array}$} & Absolute & ,161 & 106 \\
\hline & Positive & ,161 &, 070 \\
\hline & Negative &,- 100 &,- 106 \\
\hline \multicolumn{2}{|l|}{ Kolmogorov-Smirnov Z } & ,880 &, 580 \\
\hline \multicolumn{2}{|l|}{ Asymp. Sig. (2-tailed) } & ,421 & 890 \\
\hline
\end{tabular}

a. Test distribution is Normal.

b. Calculated from data.

Tabel 4. Hasil uji homogenitas data Nilai BKTZ

\begin{tabular}{|c|c|c|c|}
\hline $\begin{array}{c}\text { Levene } \\
\text { Statistic }\end{array}$ & df1 & df2 & Sig. \\
\hline 4,617 & 1 & 58 &, 063 \\
\hline
\end{tabular}

Dari out put dapat dilihat bahwa sig.= $0,063$ lebih besar dari 0,05. ( $\operatorname{sig}=0,063>0,05)$ dapat disimpulkan bahwa varian data kemampuan berpikir kritis siswa yang di ajar dengan strategi Integreted Learning dan Contextual Teaching Learning memiliki varian data yang sama atau homogen.

\section{Pembahasan}

Pada penelitian ini pengujian hipotesis dengan menggunakan uji analisis varian (ANAVA) dua jalur. Penggunaan anava ini untuk menguji hipotesis bertujuan menguji pengaruh mayor atau utama (main effect). Main effect dalam penelitian ini adalah yakni perbedaan pengaruh paket $\mathrm{A}_{1}$ strategi pembelajaran Contextual Teaching Learning (CTL) dan paket $\mathrm{A}_{2}$ strategi pembelajaran Integratif terhadap kemampuan berpikir kritis siswa tentang zakat. Hasil perhitungan ANAVA dapat dilihat pada Tabel 5.
Terdapat pengaruh strategi pembelajaran CTL dan Integratif terhadap Kemampuan berpikir kritis siswa tentang zakat.

Hipotesis statistik yang di uji adalah:

$$
\begin{array}{ll}
\mathrm{H}_{0} & : \mu_{A 1} \leq \mu_{A 2} \\
\mathrm{H}_{1} & : \mu_{A 1}>\mu_{A 2}
\end{array}
$$

Berdasarkan hasil pengujian hipotesis diperoleh hasil uji bahwa hipotesis nol ditolak yang menyatakan tidak terdapat perbedaan "kemampuan berpikir kritis siswa tentang zakat yang mengikuti pembelajaran dengan paket strategi CTL $\left(\mathrm{A}_{1}\right)$ dan Instructional Integratif $\left(\mathrm{A}_{2}\right)$. Hal ini dapat terlihat Hasil perhitungan uji Anava Dua Arah yang dilakukan dengan bantuan program SPSS 22 for Windows dapat dilihat bahwa sig (2-tailed) pada T-Test Equality of Means sebesar 0,003 lebih kecil dari 0,05 (sig. $=0,003<0,05$ ). Hal ini berarti hipotesis nol ditolak.

Dengan demikian dapat disimpulkan bahwa terdapat perbedaan kemampuan berpikir kritis siswa tentang zakat antara yang

\section{Hipotesis}


memperoleh strategi CTL dan Instructional Integratif. Hal ini berarti hipotesis kerja diterima dan hipotesis nol ditolak. Dengan hasil uji hipotesis di atas, ini berarti menunjukkan bahwa strategi pembelajaran CTL lebih baik pengaruhnya bagi siswa terhadap kemampuan berpikir kritis siswa tentang zakat dari pada strategi pembelajaran Integratif Instructional.

Berdasarkan temuan hasil penelitian dari hasil uji hipotesis dapat dijelaskan, merujuk kepada hasil pengujian hipotesis, bahwa terdapat perbedaan yang signifikan kemampuan berpikir kritis siswa tentag zakat yang diberikan strategi pembelajaran CTL dan Instructional Integratif. Hal ini terlihat pada tabel ANAVA, F Fitung 4,617 lebih kecil dari $\mathrm{F}_{\text {tabel }} 4,17$ pada taraf signifikan 5\%. Data skor rata-rata siswa yang mengikuti paket strategi pembelajaran Cotextual Teaching Learning (CTL) 78,96 lebih besar dari skor rata-rata siswa yang mengikuti paket strategi pembelajaran Instructional Integratif 72,86 .

Tabel 5. Ringkasan hasil uji anava satu arah pengaruh paket strategi pembelajaran Contextual Teaching Learning (CTL) dan integratif learning terhadap kemampuan berpikir kritis siswa tentang zakat

Independent Samples Test

\begin{tabular}{|c|c|c|c|c|c|c|c|c|c|c|}
\hline & \multicolumn{2}{|c|}{$\begin{array}{l}\text { Levene's } \\
\text { Test for } \\
\text { Equality of } \\
\text { Variances } \\
\end{array}$} & \multicolumn{7}{|c|}{ t-test for Equality of Means } \\
\hline & & \multirow[t]{2}{*}{$\mathrm{F}$} & \multirow[t]{2}{*}{ Sig. } & \multirow[t]{2}{*}{$\mathrm{T}$} & \multirow[t]{2}{*}{ df } & \multirow{2}{*}{$\begin{array}{l}\text { Sig. } \\
(2- \\
\text { tailed })\end{array}$} & \multirow{2}{*}{$\begin{array}{l}\text { Mean } \\
\text { Differ } \\
\text { en ce }\end{array}$} & \multirow{2}{*}{$\begin{array}{c}\text { Std. } \\
\text { Error } \\
\text { Differen } \\
\text { ce }\end{array}$} & \multicolumn{2}{|c|}{$\begin{array}{l}95 \% \text { Confidence } \\
\text { Interval of the } \\
\text { Difference }\end{array}$} \\
\hline & & & & & & & & & Lower & Upper \\
\hline $\begin{array}{l}\text { Nilai } \\
\text { BKT } \\
\text { Z }\end{array}$ & $\begin{array}{l}\text { Equal } \\
\text { variances } \\
\text { assumed } \\
\text { Equal } \\
\text { variances } \\
\text { not } \\
\text { assumed }\end{array}$ & 4,617 & ,036 & $\begin{array}{r}- \\
3,062 \\
- \\
3,062\end{array}$ & 52,311 & ,003 & $-6,100$ & 1,992 & $-10,088$ & $-2,103$ \\
\hline
\end{tabular}

\section{Interpretasi/Pembahasan Dengan Mengacu kepada Teori}

Berdasarkan hasil yang diperoleh tersebut dapat dijelaskan bahwa siswa yang mengikuti paket strategi pembelajaran CTL memiliki kemampuan berpikir kritis siswa tentang zakat lebih tinggi di bandingkan dengan siswa yang mengikuti paket strategi pembelajaran Integratif Instructional, secara empirik terbukti bahwa kedua strategi tersebut memiliki perbedaan yang signifikan.

Kedua strategi di atas sekalipun samasama berorientasi pada student fokus dan sama-sama melibatkan siswa secara aktif dalam kegiatan pembelajaran, tetapi memiliki perbedaan, diantaranya adalah pertama, pada CTL diawali dengan pengamatan (observation) dan Integreted Insgructional mengidentifikasi topik, kedua hal tersebut sangat berbeda, pada observasi, siswa dilibatkan untuk belajar dengan seksama berbagai permasalahan secara empirik dan teoritik, sementara pada Integreted Instructional siswa masih melakukan identifikasi topik. Pada CTL siswa telah masuk dalam permasalahan secara komprehensif sementara pada Integreted Instructional siswa masih berputar pada hal-hal yang bersifat makro.

Kedua, pada CTL siswa telah memiliki pertanyaan penelitian atau research question, berhipotesis untuk mengeksplorasi secara mendalam terkait dengan permasalahan zakat secara teoritik dan empirik, sementara pada Integreted Instructional siswa di arahkan oleh guru untuk menggapai sesuatu dari tujuan pembelajaran. 
Ketiga, pada CTL siswa telah berhipotesis dari kerangka teoritik yang sudah mereka pelajari secara mendalam dan mendetail dari beberapa buku refrensi yang sudah disiapkan oleh guru, sementara pada Integreted Instructional siswa masih bergulat pada tataran mempersiapkan data, menggali dan mempelajarinya.

Keempat, CTL telah memiliki data sesuai dengan hipotesis yang sudah terbangun dari kerangka teoritik yang sudah dikupas bersama guru, sementara pada Integreted Instructional guru sudah langsung untuk mempresentasikan data yang sudah ditemukan. Penyampaian data pada Integreted Instructional umum, karena dari awal tidak dipandu untuk melakukan kerangka konseptual dan kerangka teoritik, sehingga cendrung arah berpikirnya induktif, menemukan apa adanya dan membahas apa adanya, tidak selektif dan fokus seperti pada CTL. Sekalipun sama menyampaikan data, tetapi data pada Integreted Instructional terlalu umum, karena merangkum berbagai hal, dalam beberapa perspektif, sementara CTL dipandu dengan kerangka research, lebih fokus dan lebih sistematis, sehingga membuat siswa terlatih berpikir kritis.

Kelima, kesimpulan antara CTL dan Integreted berbeda, pada CTL telah menemukan sesuatu dari bangunan kerangka berpikir yang sudah terpola dengan rapi, pada Integreted Instructional menemukan sesuatu yang baru untuk dibahas lagi ke arah pembahasan berikutnya. Pada CTL siswa menemukan novelty sementara pada integreted siswa memulai pekerjaan baru.

Dengan lima perbedaan di atas dapat terlihat dengan jelas, bahwa CTL dan Integreted Instructional sangat berbeda dalam mempengaruhi kemampuan berpikir siswa. Temuan empirik dari penelitian yang sudah dilakukan, sangat sejalan dengan alur dan strategi pembelajaran yang dilakukan oleh dua model pembelajaran tersebut. Dimana terlihat bahwa CTL seperti yang dijelaskan oleh Wasis, memiliki ciri khusus, yaitu menyediakan berbagai fitur sehingga konten dalam perangkat dapat dikaitkan dengan kehidupan nyata, serta memiliki berbagai pilihan aktivitas sehingga siswa dengan berbagai gaya belajar dan tingkat kemampuan dapat melakukan hand on activities dan mind on activities sesuai dengan lingkungan belajarnya. ${ }^{38}$ Model pembelajaran CTL lebih menekankan pembelajaran berpusat kepada siswa, waktu pembelajaran digunakan oleh siswa untuk membangun pengetahuannya sendiri melalui berbagai kegiatan, antara lain praktikum, diskusi, presentasi, mengerjakan LKS atau tugas-tugas lain, membaca untuk menemukan konsep atau kalimat-kalimat kunci. Peran guru dalam bentuk pembimbingan tetap dibutuhkan selama kegiatan-kegiatan tersebut, tetapi lebih bersifat fasilitator bukan decision maker. ${ }^{39}$ Dengan demikian sangat logis bahwa CTL lebih berpengaruh terhadap peningkatan kemampuan berpikir kritis siswa tentang zakat dibandingkan dengan strategi pembelajaran Integreted Instructional. Dimana lebih layak di gunakan oleh guru dalam rangka pengembangan wawasan siswa tentang berbagai perspektif dalam membicarakan permasalahan agama, sosial, budaya dan politik. Tentu hal ini diperlukan penelitian berikutnya yang berkaitan dengan kemampuan siswa mengembangkan wawasan dan cakrawala berpikir.

\section{PENUTUP}

Dari hasil penelitian dan pembahasan di atas dapat peneliti simpulkan bahwa dalam rangka pengembangan kemampuan berpikir kritis siswa tentang zakat, perlu mengembangkan strategi pembelajaran Contextual Teaching Learning (CTL).

Implikasi hasil penelitian adalah berkenaan dengan upaya meningkatkan kemampuan berpikir kritis siswa tentang zakat dengan mempertimbangkan faktor strategi pembelajaran CTL. Bahwa paket strategi pembelajaran Contextual Teaching Learning (CTL), diharapkan dapat menjadi tambahan wawasan bagi guru dalam mengajarkan Pendidikan Agama Islam kepada siswa. PAI memiliki peranan penting dalam membentuk sikap, menuntun akhlaq, memperkuat tauhid dalam menjalankan kehidupan. Oleh sebab itu di perlukan strategi pembelajaran yang efektif,

${ }^{38}$ Wasis, Contextual Teaching and Learning (CTL) Dalam Pembelajaran Sains-Fisika SMP (Surabaya: Jurnal Cakrawala Pendidikan, Februari 2006 Tahun XXV No. 1), hal. 14.

${ }^{39}$ Loc. cit., 
supaya PAI menjadi pembelajaranan yang inovatif dan menyenangkan siswa. Dengan adanya penelitian ini dapat menjadi tambahan reffrensi bagi guru dan siswa dalam memilih strategi pembelajaran.

Berdasarkan kesimpulan dalam penelitian ini maka dapat disampaikan beberapa saran sebagai berikut: pertama, perlu mengembangkan dan menggunakan paket strategi pembelajaran Contextual Teaching Learning (CTL). Pelaksanaan paket strategi pembelajaran ini sebagai alternatif bagi guru dalam peningkatan kemampuan berpikir kritis. Telah terbukti dari hasil penelitian ini bahwa paket strategi Contextual Teaching Learning (CTL) lebih tinggi kemampuan berpikir kritis siswa dari pada paket strategi pembelajaran Integreted Instructional. Maka paket strategi pembelajaran Contextual Teaching Learning (CTL) ini dapat terus digunakan dan dikembangkan di sekolah.

Kedua, perlu membuat kurikulum yang lebih mengedepankan pada pengembangan kemampuan berpikir kritis siswa. Karena dengan kemampuan berpikir kritis yang tinggi menjadikan siswa lebih senang dalam mengikuti pembelajaran. Ketiga, jumlah siswa yang sedikit, perlu diperbesar lagi supaya hasilnya lebih representatif dan memperoleh gambaran yang lebih akurat dari efek perlakuan. Penelitian ini hanya melibatkan satu pelajaran PAI yang di dalamnya terintegrasi materi zakat. CTL dan integreted Instructional dapat dilakukan dengan mata pelajaran lain dengan mengembangkan atribut sikap siswa terhadap mata pelajaran tersebut, kepedulian, gaya belajar dan motivasi belajar.

\section{UCAPAN TERIMA KASIH}

Penelitian ini dapat terealisasi dengan baik karena mendapat dukungan dari banyak pihak. Oleh karena itu, kami ucapkan terima kasih atas kerja sama dan dukungannya, terutama kepada Bapak Kepala Puslitbang Pendidikan Agama dan Keagamaan. Kami ucapkan terima kasih kepada Rektor Universitas Ibnu Chaldun (UIC) dan Dekan Fakultas Agama Islam (FAI) yang telah memberikan tugas. Kepala Sekolah SMP Islam Terpadu Assalam yang telah membukakan pintunya kepada peneliti untuk melakukan pengambilan data, dan melaksanakan beberapa treatment untuk menguji keandalan strategi pembelajaran. Teman-teman guru yang telah banyak meluangkan waktu untuk berdiskusi dan memberikan data. Kami hanya mendoakan semoga Allah SWT memberikan ganjaran pahala terhadap amal shaleh yang telah kita kerjakan ini.

\section{DAFTAR PUSTAKA}

Al-Qardawi, Y. (1993). Fiqhuz Zakat Jakarta: Litera AntarNusa.

Dewey, John. (2012). Critical Thinking dalam Kasdin Sihotang dan Febiana

Rima, K. Jakarta: Pustaka Sinar Harapan.

Edward. Glaser. (1994). An experiment in the Development of Critical Thinking Columbia: Teacher's College Columbia University.

Eggen, Paul. (2012). Strategi dan Model Pembelajaran Mengajarkan Konten dan Keterampilan Berpikir Jakarta : Indeks.

Elaine B. (2002). Contextual Teaching Learning California: Thousan Oak.

El-Din, S. I. T. (1986). Allocative and Stabilizing Functions of Zakat in an Economy. Journal of Islamic Banking and Finance, Vol. 3:4.

Fauzan, Model-Model Pembelajaran Integratif. http://bdkbandung.kemenag.go.id/jurnal/ 324-model-pembelajaran-integratif (diakses 28 Oktober 2017).

Fogarty F. (1991). How to Integrative The Curricula Palatine, Illionis: Skygh Publishing Inc.

Gall, D. 1998). Educational Research New York: Longmann.

Hafidhuddin D. (2002). Zakat dalam Perekonomian Modern Jakarta: Gema Insani Press.

Indah, Sugiarti. (2007). Implementasi Model Pembelajaran Integratif Exploratif Dalam Pembelajaran Bahasa Indonesia di SMP.

Johnson. (2007). Contextual Teaching Learning Menjadikan Kegitan BelajarMengajar Mengasyikkan dan Bermakna (Bandung: Mizan Media Utama.

Kasihani. (2002). Contextual Teaching and Learning (CTL) Pengajaran dan Pembelajaran Kontekstual Malang: Jurnal Vol. 2.

Meredith D. (2007). An Introduction Educational Research Boston: Pearson. 
Paul. (1998). Logic as Theory of Validation: An essay in Philosophical logic Santa Barbara: University of California.

Peraturan Pemerintah Nomor 19 Tahun 2005 tentang Standar Nasional Pendidikan, pasal 19, ayat 1,2 dan 3 .

Peter. (1993). Paulo Freire: A Critical Encounter London \& New York: Routledge.

Pohan. (2015). Pengaruh Penggunaan Model Pembelajaran Integratif Terhadap Hasil Belajar Sifat Koligatif Larutan. Jurnal Wahana Inovasi Vol. 4 No. 1 Tahun 2015.

Pope, Stenberg Rob. (2005). Creativity: Theory, History, and Practice London \& New York: Routledge.

Robert H. (1996). A concept of critical thinking (Cambridge: Harvard Educational Review, Vol 32 (1).

Rostiawati, Tita. (2013). Penerapan Model Pembelajaran CTL Pada Bahan Ajar Geometri dan Pengukuran di Sekolah Dasar Bandung: UPI Press.
Sabiq, Sayyid. (2006). Figih Sunnah Jakarta: Pena Pundi Aksara.

Santrock, John W. (2011). Psikologi Pendidikan, Jakarta: Salemba Humatika.

Shaughnessy, Jhon J. (2012). Research Methods in Psychology New York: McGraw-Hill.

Sunhaji. (2014). Model Pempelajaran Integratif Pendidikan Agama Islam dengan dengan Saint. Jurnal Insania, Vol. 19, No. 2. Purwakarta.

Trianto. (2009). Mendesain Model Pembelajaran Inovatif-Progresif Konsep, Landasan, dan Implementasinya Pada Kurikulum Tingkat Satuan Pendidikan (KTSP) Jakarta: Kencana Prenada Media Group.

Wasis. (2006). Contextual Teaching and Learning (CTL) Dalam Pembelajaran Sains-Fisika SMP (Surabaya: Jurnal Cakrawala Pendidikan, Februari 2006 Tahun XXV No. 1). 